\title{
SEISMICITY IN ANTARCTICA
}

\author{
Katsutada KAMINUMA \\ National Institute of Polar Research, Tokyo, Japan \\ (Received August 9, 1976)
}

The Antarctic Continent and the surrounding ocean, which is called the Antarctic plate, enclosed by marginal seismic belts is one of the large aseismic areas on the earth, though there are actjve volcanoes in West Antarctica and the Ross-Weddell Graben. More than ten seismological stations have been established in Antarctica since International Geophysical Year (IGY) of 1957. However no earthquakes have been located in the Antarctic area by the World Wide Seismological Station Network (WWSSN), with the exception of volcanic eruptions of Deception Island.

"The Antarctic Seismological Bulletin" has been published on the basis of phase readings from the Antarctic Seismological Stations. The events for which the phase readings of $P$ wave arrival time were reported from more than four stations, but for which the hypocenter determination was not made, were found in the bulletin.

Seismograms at Japanese Antarctic Station, Syowa, in Lützow-Holm Bay, East Antarctica, seem to indicate the occurrence of some micro-earthquakes. This fact suggests the possibility of the occurrence of small/microearthquakes in other part of the Antarctica.

The present paper attempts to confirm the existence of earthquakes in Antarctica on the basis of the data from WWSSN and of temporary seismological observations at some stations in Antarctica.

The main results are summarized as follows:

1) Small earthquakes occur at least in West Antarctica and in the Ross-Weddell Graben, though the activity is very low. But the earthquakes are not generally detectable by the insufficient seismological network in Antarctica.

2) The seismicity around Syowa Station in East Antarctica is less than one micro-earthquake per month. However earthquakes occur in the marginal zone of East Antarctic Shield area.

3) The seismicity around the Dry Valleys in Victoria Land is one micro- or ultra micro-earthquake every two days and that around McMurdo Station on Ross Island is one earthquake per day.

4) The seismic activity in the volcanic region in the Antarctic is relatively higher than that in the surrounding region.

5) The seismicity in West Antarctica and in the Ross-Weddell Graben is some ten times higher than that in East Antarctica. 


\section{Introduction}

The Antarctic Continent and the surrounding ocean, which is called the Antarctic plate, enclosed by marginal seismic belts is one of the large aseismic areas on the earth. More than 10 seismological stations have been established in Antarctica since International Geophysical Year(IGY) of 1957. But no earthquakes have been located in the Antarctic area by the World Wide Seismological Station Network (WWSSN), which can detect almost all earthquakes in the world with magnitude more than five.

The geological and geographical features of the Antarctic Continent are roughly divided, as shown in Fig. 1, into three parts; East Antarctica, West Antarctica, and the Ross-Weddell Graben. East Antarctica has remained an essentially stable continental shield since before the Devonian. The orogenic belts in West Antarctica are composed of Mesozoic and Cenozoic rocks with volcanics. The topography under the continental ice sheet indicates that these belts are an island arc.

The Ross-Weddell Graben has been an orogenic belt since the middle of the Mesozoic and is situated between the two dissimilar tectonic regions of East and West Antarctica. The Transantarctic Mountains, which have been an orogenic belt since the early Paleozoic, divide East Antarctica and the Ross-Weddell Graben.

Two active volcanoes, Deception Island and Mt. Erebus, are located, re-

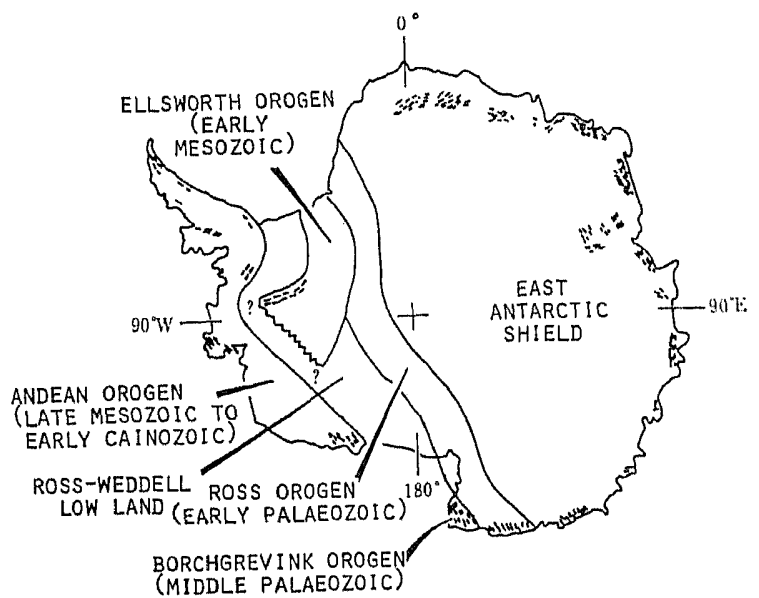

Fig. 1. The geological and geographical features of the Antarctic Continent. East Antarctica: part of the continent, chiefly east of Greenwich that lies south and west of the Ross Sea and south and east of the Weddell Sea. West Antarctica: the Antarctic Peninsula and Marie Byrd Land. Ross-Weddell Graben: the Ellsworth Mountains and Victoria Land. 
spectively near the top of the Antarctic Peninsula in West Antarctica and on Ross Island in the Ross-Weddell Graben.

With the exception of the volcanic eruptions of Deception Island, no significant earthquake has ever been located in Antarctica; however the occurrence there of small magnitude events has been recognized for some time. Since the IGY, the seismic activity of this region has been studied by many workers (e.g., Hatherton, 1961; HATHERTON and Evison, 1962; Kogan et al., 1965; LaZareva and Sytinskiy, 1965; Browne-Cooper et al., 1967; Evison, 1967; Kaminuma, 1971). Some of them found strong evidence that many shocks recorded at the Antarctic Stations originated from the calving of icebergs or cracking of the ice sheet. Although others have reported some shocks in the Antarctic region, these shocks were not confirmed clearly by other investigators. In any case, with the exception of the discoveries of ADAMs (1969), no earthquakes have been located in the Antarctic Continent.

The present paper attempts to confirm the existence of earthquakes in Antarctica on the basis of the data from WWSSN and of temporary seismological observations at some stations in Antarctica.

\section{Small Earthquakes in the Continent}

The USNOAA (formerly USCGS) had published "The Antarctic Seismological Bulletin" on the basis of phase readings received telegraphically from the Antarctic Seismological Stations. Some of these readings of $P$ wave arrival time were not used by NOAA for hypocenter location, probably because no corresponding phase readings were available from other seismological stations outside Antarctica. Those events for which the phase readings of $\mathbf{P}$ wave arrival time were reported in the bulletin from more than four stations, but for which the hypocenter determination was not made, were used by Kaminuma and Ishida (1971b) for trial location. The period from 1966 through 1969 was examined.

Only 24 events out of the 72 events which were studied could be located as shown in Fig. 2. The standard error of the calculation of the hypocenter locations is within $100 \mathrm{~km}$ in the epicenter coordinates, and $\mathrm{O}-\mathrm{C}$ residual is less than $3 \mathrm{sec}$. The epicenters of most of these events are located in and near the existing seismic belts. The open circles in Fig. 2 are the events for which the hypocenter were located by using $\mathrm{P}$ wave arrival time from seismological stations in Antarctica shown by the closed circles.

Only one event, which occurred on June 26, 1968, was located in the Antarctic Continent, near $20^{\circ} \mathrm{W}$ and $80^{\circ} \mathrm{S}$. The stations used for the hypocenter location were SANAE(SNA), South Pole(SPA), Byrd(BYR), one of the 


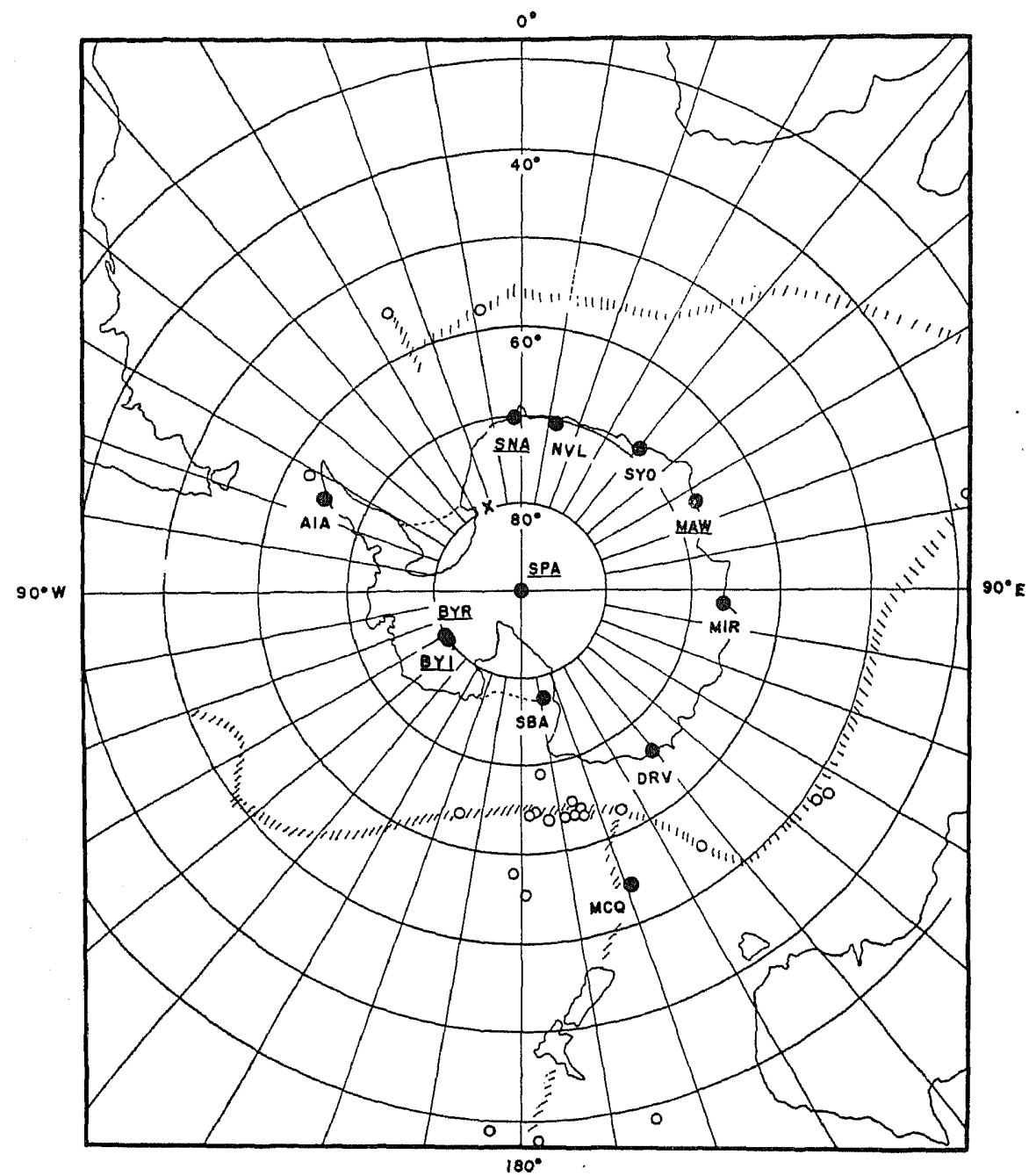

Fig. 2. Earthquakes located in and around Antarctica for the period 1966 through 1969. Open circles indicate the epicenters. Solid circles indicate the seismological stations. The hatched area indicate the seismic belt (KAMINUMA and ISHIDA, 1971b).

branch stations of Stanford Network at Byrd(BY1), and Mawson(MAW). After examining the location accuracy of this event, the hypocenter of the event is determined as follows;

$\begin{array}{ll}\text { Origin time } & 18 \mathrm{~h} 20 \mathrm{~m} 52.8 \mathrm{~s} \\ \text { Latitude } & 79.56^{\circ} \mathrm{S} \\ \text { Longitude } & 20.33^{\circ} \mathrm{W} \\ \text { Depth } & 1 \mathrm{~km} \text { (below sea level) } \\ \text { Magnitude } & 4.3\end{array}$


The altitude of the area where this event took place is between $1,000 \mathrm{~m}$ and $1,500 \mathrm{~m}$, and the ice thickness is estimated to be less than $1,000 \mathrm{~m}$. The event occurred in the basement rock, as its depth was $1 \mathrm{~km}$ below sea level. Therefore, the event must have been an earthquake, and this may be the first instrumentally recorded evidence of such an earthquake occurrence in Antarctica.

The event located in the northern edge of the Shackleton Range which is east of the Filchner Ice Shelf at the head of the Weddell Sea. The geological surveys of this range have been carried out by the field parties of the British Antarctic Expedition (Stephenson, 1966; Clarkson, 1972). It is pointed out by Clarkson (private communication) that the event may be related to the major fault zone beneath Slessor Glacier which separates the Precambrian and Lower Palaeozoic rocks of the Shackleton Range from the Upper Palaeozoic sandstones and Jurassic intrusions of the Theron Mountains.

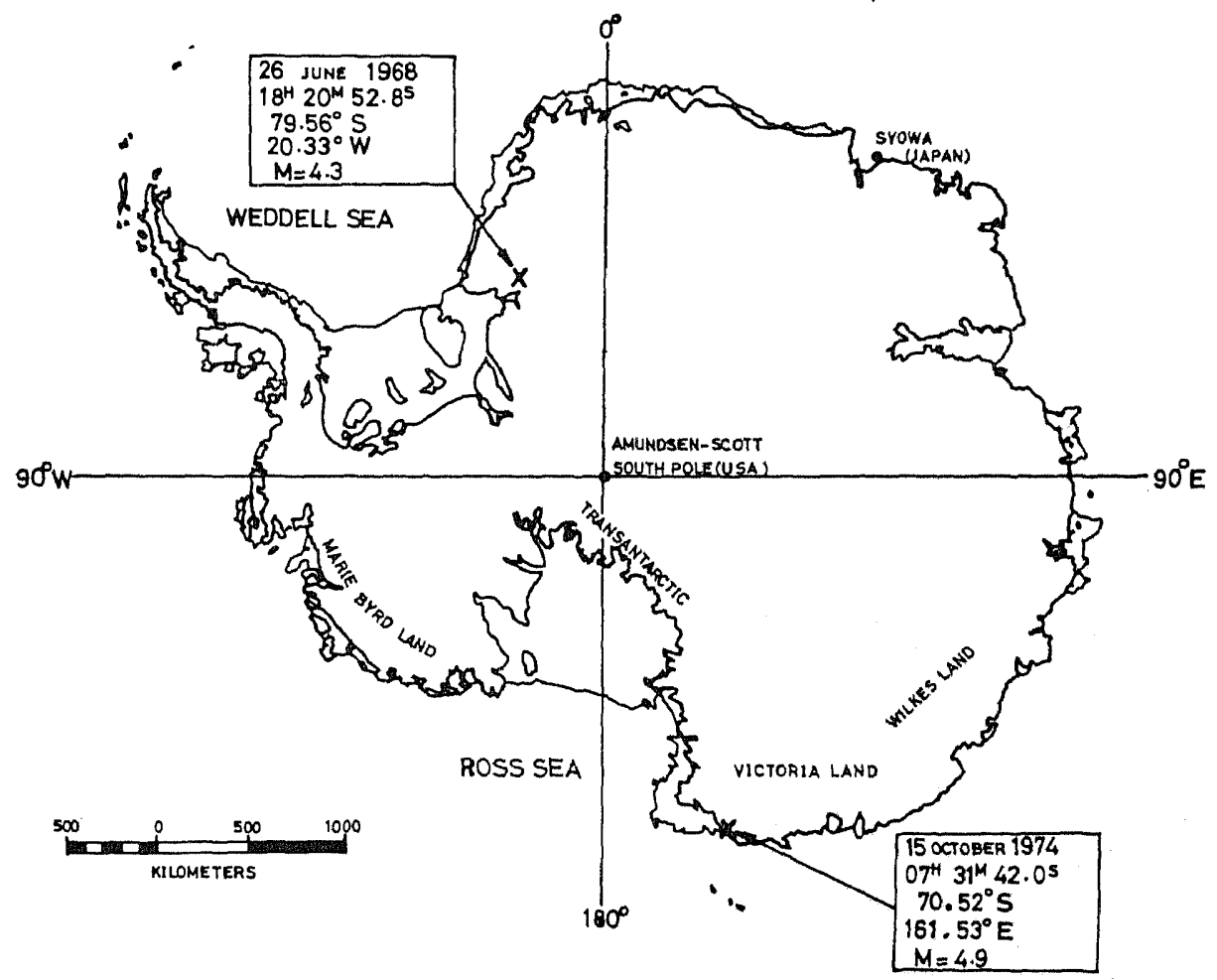

Fig. 3. Two small earthquakes located in the Antarctic Continent. One earthquake which occurred on June 26, 1968 was determined by Kaminuma and IsHidA (1971b). The other earthquake which occurred on October 15, 1974 was determined by NOAA. 
The event is considered as an earthquake from the geological structure of the area where it occurred.

One earthquake which was located in the northern part of Victoria Land occurred on October 15, 1974. The location of the hypocenter was determined by NOAA using data from 12 stations. The results are as follows;

$\begin{array}{ll}\text { Origin time } & 07 \mathrm{~h} 31 \mathrm{~m} 42.0 \mathrm{~s} \pm 0.48 \mathrm{~s} \\ \text { Latitude } & 70.518^{\circ} \mathrm{S} \pm 7.3 \mathrm{~km} \\ \text { Longitude } & 161.538^{\circ} \mathrm{E} \pm 10.8 \mathrm{~km} \\ \text { Depth } & 33 \mathrm{~km} \\ \text { Magnitude } & 4.9\end{array}$

The epicenters of both earthquakes discussed above are given in Fig. 3. The two earthquakes occurred in the marginal zone of the Transantarctic Mountains, which is thought to be a tectonically active area. These two events show that minor earthquake activity occurs in Antarctica, though it is not generally detectable by the insufficient seismological network presently available.

\section{Earthquakes around Syowa Station}

The seismological observations at the Japanese Antarctic Station, Syowa have been carried out since 1957 except for 4 years, 1962-65 (KAmINuma, 1969). Syowa Station is located on Ongule Island, Lützow-Holm Bay, which is the marginal zone of the East Antarctic shield area. Sometimes small or micro-earthquakes are recorded by the three component HES seismograph at Syowa Station. Many ice shocks are also recorded. But it is not difficult to distinguish between earthquakes and ice shocks from their wave forms (KAMINUMA, 1971; KAMINUMA and Ishida, 1970a). A typical record of these earthquakes is given in Fig. 4.
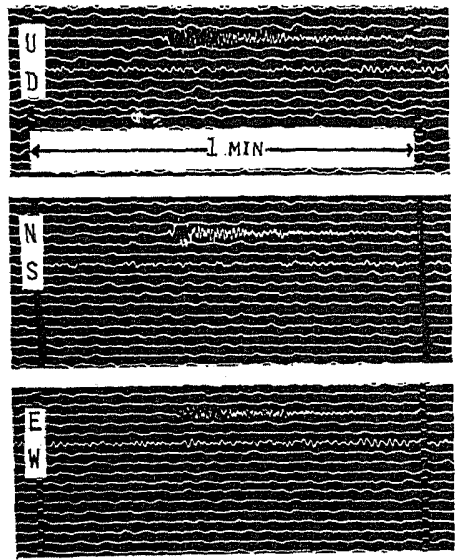

Fig. 4. A typical seismogram of micro-earthquakes recorded by the HES seismograph at Syowa Station. This shock occurred on January 29 , 1970. 


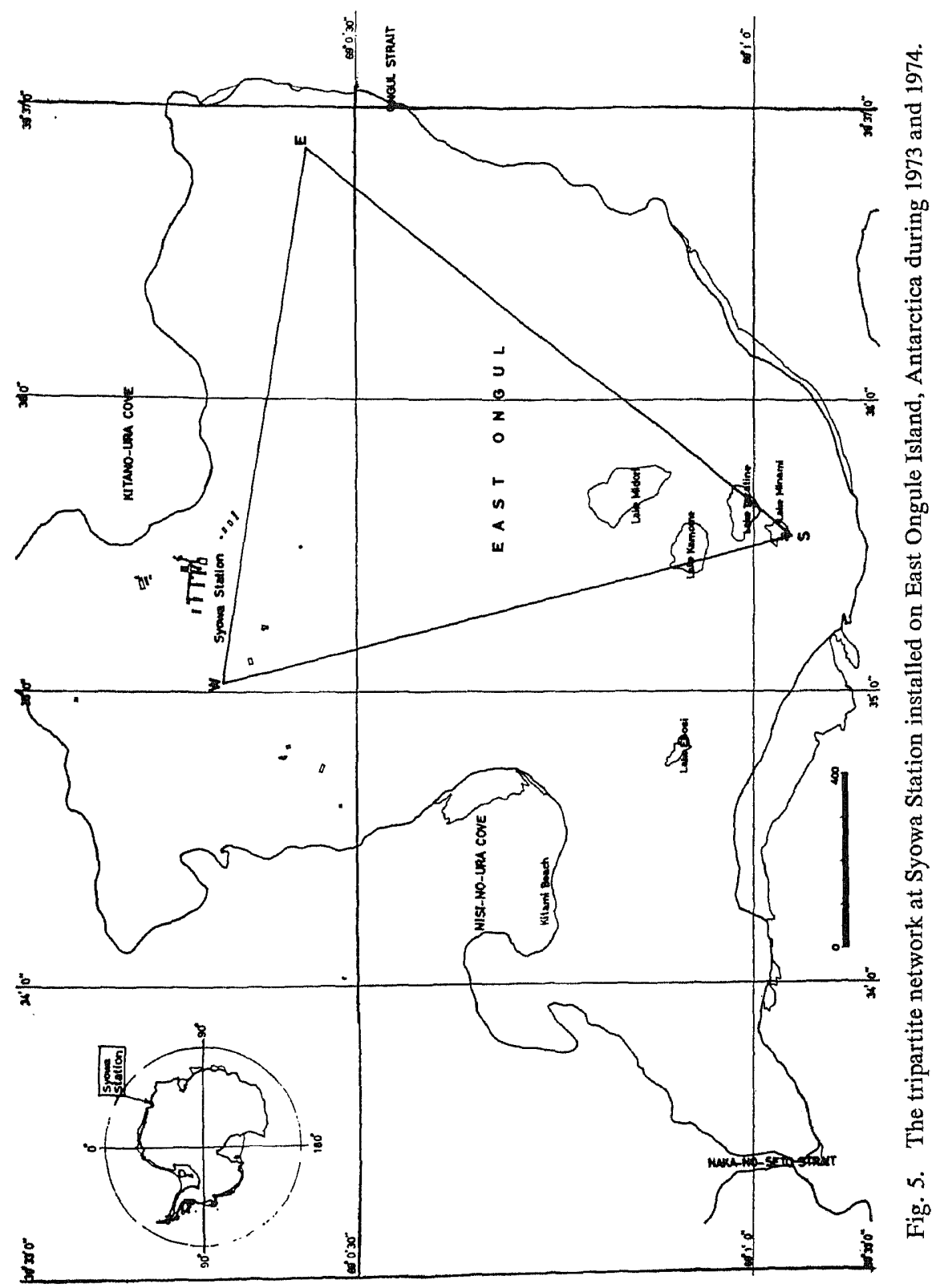


For the purpose of determining the location of micro-earthquakes, seismological observations using a tripartite network were made at Syowa Station in the winter season of 1973 (TAKaHASH et al., 1975). Three seismographs with 1.0-sec period were installed on East Ongule Island. The location of the seismographs is shown in Fig. 5. A magnetic tape recorder and three

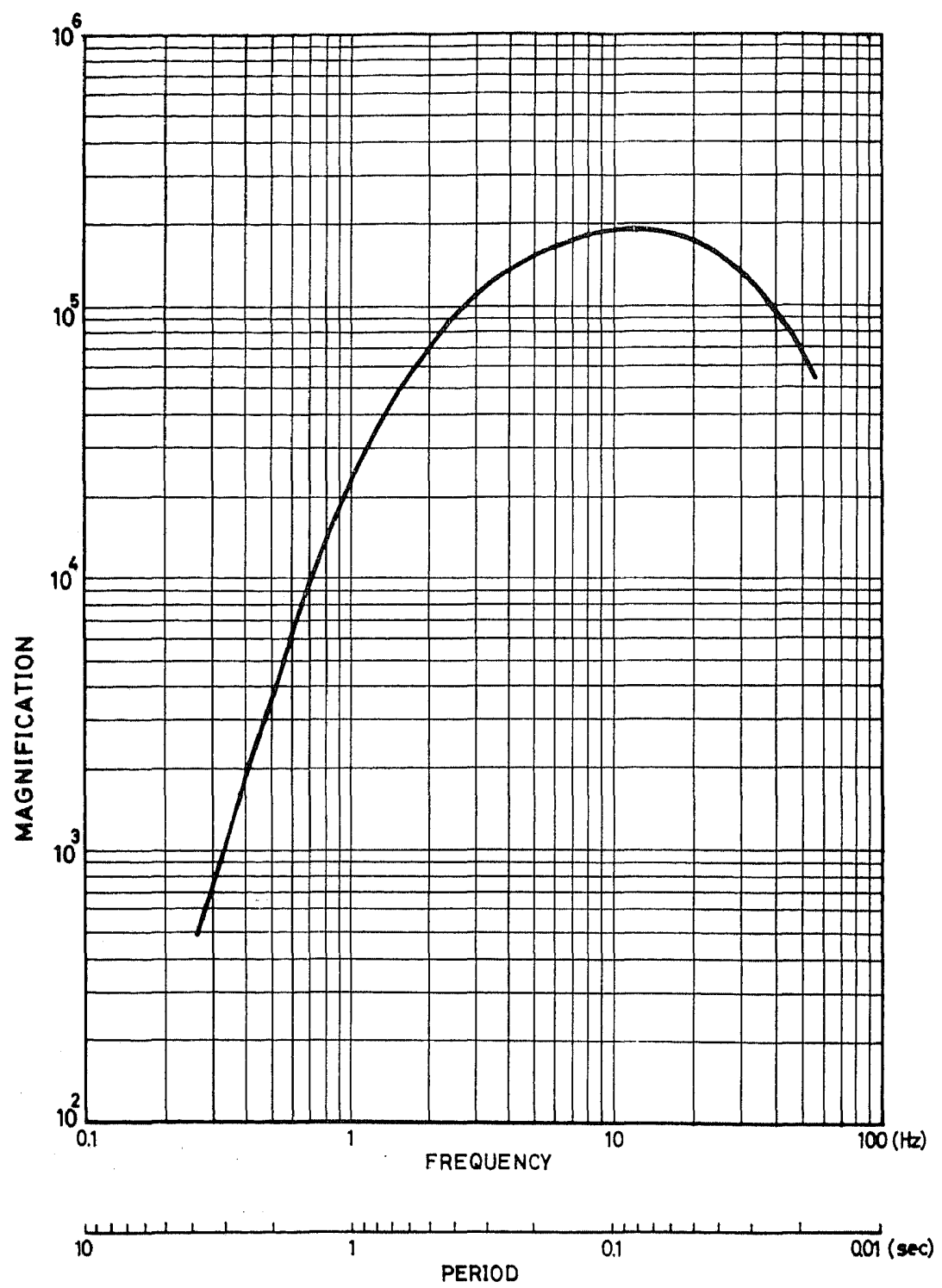

Fig. 6. Magnification curve vs. frequency for the seismographs used in the tripartite network at Syowa Station. 


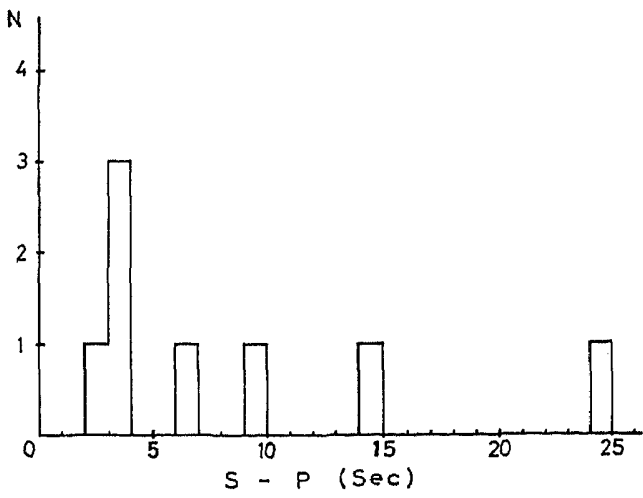

Fig. 7. Frequency of S-P times of earthquakes recorded by the tripartite network at Syowa Station.

drums were used as a data recording system. The tape recorder has four channels, three for seismographs and one for the crystal clock. The system operated during a period of low microseisms. Because the seismographs placed on the basement rocks were covered with wooden boxes, the observations were frequently disturbed by wind noise.

The observations were carried out with a maximum magnification of 50,000 . Figure 6 is a graph of magnification against frequency for the system.

Only eight earthquakes were recorded during the 10 -month period. The frequency of S-P times is shown in Fig. 7. Six out of the eight has less than $10 \mathrm{sec}$ S-P times. The magnitudes of these earthquakes were estimated to be between 0 and 1 .

The locations of two of the eight earthquakes were determined, but the other six earthquakes were not determined because of instrumental malfunction and/or extreme microseisms.

One of the two earthquakes which was located had an epicenter about $20 \mathrm{~km}$ west-north-west of Syowa Station and the other was $50 \mathrm{~km}$ west. The depth of the both was about $10 \mathrm{~km}$ below mean sea level.

Two of the six earthquakes which were not located have the same wave form and nearly the same S-P times as the earthquake originating $20 \mathrm{~km}$ WNW of Syowa Station. Therefore, these two earthquakes were estimated to be also located about $20 \mathrm{~km}$ west of Syowa Station.

It is an interesting fact that the earthquakes occurred on the oceanic side of Syowa Station on Ongule Island, though only a few hypocenters could be located precisely. The surface features of the island indicate that they were covered with glacial ice several thousand years ago and are now going through a rebounding movement associated with the retreat of the glacier. The microearthquakes which occurred around Syowa Station were probably caused by a release of strain due to this isostatic rebound after glaciation. 
The seismicity around Syowa Station is less than one earthquake per month. This data shows that ultra micro- and/or micro-earthquakes occur at least in the marginal zone of East Antarctica, though the activity is very low.

\section{Seismicity around McMurdo Sound}

For the purpose of observing micro-earthquakes around the McMurdo Sound area and volcanic earthquakes around Mt. Erebus, seismological observations were carried out in the summer seasons of 1974-75 and 1975-76, as one of the projects of the Dry Valley Drilling Project(DVDP) (Kaminuma, 1976).

The McMurdo Sound area is located between the Antarctic Continent and Ross Island, in the middle of the western part of the Ross Sea shown in a local map of McMurdo Sound in Fig. 8. Ross Island is volcanic, with one active volcano, Mt. Erebus. The Transantarctic Mountains trend from north to south on the west side of McMurdo Sound. On the sound side of the Transantarctic Mountains are several snow-free valleys, called Dry Valleys. For

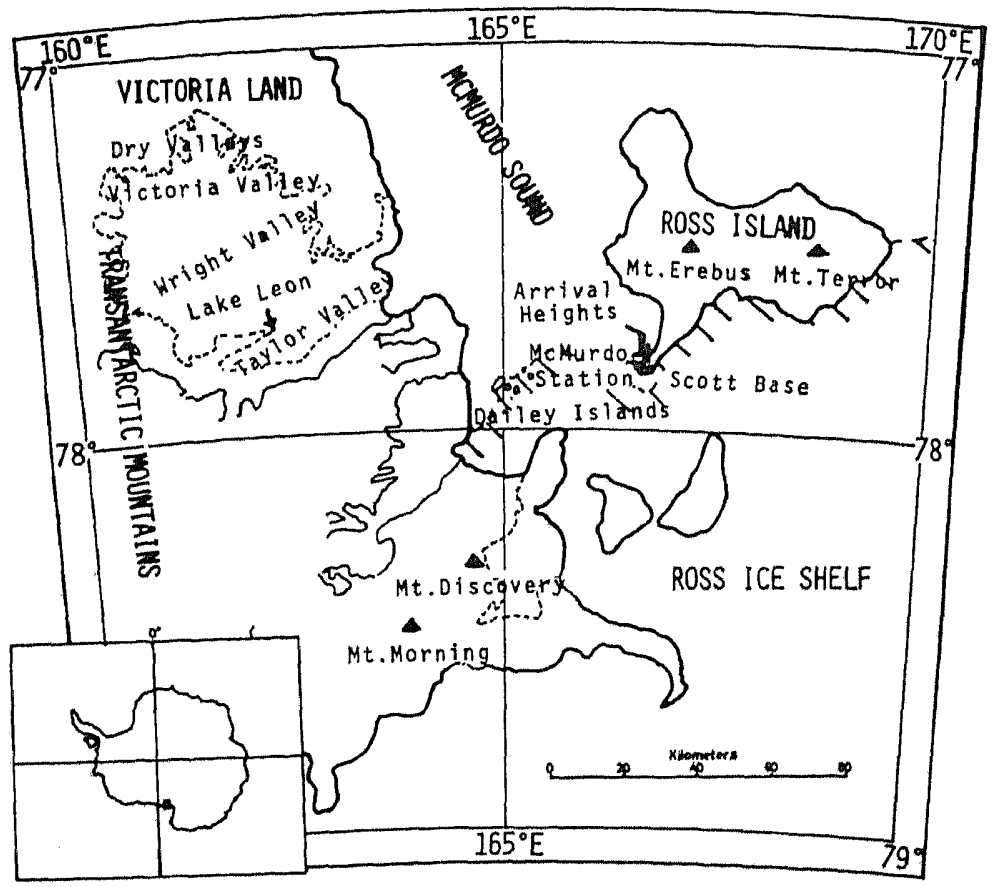

Fig. 8. Local map of McMurdo Sound. Lake Leon is a small lake in the middle of Taylor Valley. Arrival Heights is located in the north-eastern part of McMurdo Station, Ross Island. 
the purpose of finding the reasons for the formation of the dry valleys, DVDP was carried out by scientists from Japan, New Zealand and the United States in the austral summer seasons from 1971 to 1976.

The McMurdo area is not suitable for seismic observation because it is covered with thick layers of volcanic ejecta, mainly lapilli.

A tripartite seismological observation was made at Arrival Heights near McMurdo Station during 3 weeks in 1974-75. Arrival Heights consists of two small craters, First and Second Craters. A wide area for the tripartite observation was not available at Arrival Heights. Even so, it it the best site for making observations, considering the geological limitations of any McMurdo Station site.

Three seismographs were installed, one near First Crater, another near Second Crater, and the third near the aeronomical observation but of Scott base on Arrival Heights.

A cassette data recorder with a magnification of $10^{5}$ was used for the observation. The observation was disturbed frequently by high ground noise because of windy weather conditions and the high magnification of the recording system. The data for a total of only one week are available. Hypo-

Time sequence of earthquake occurrence at McMurdo

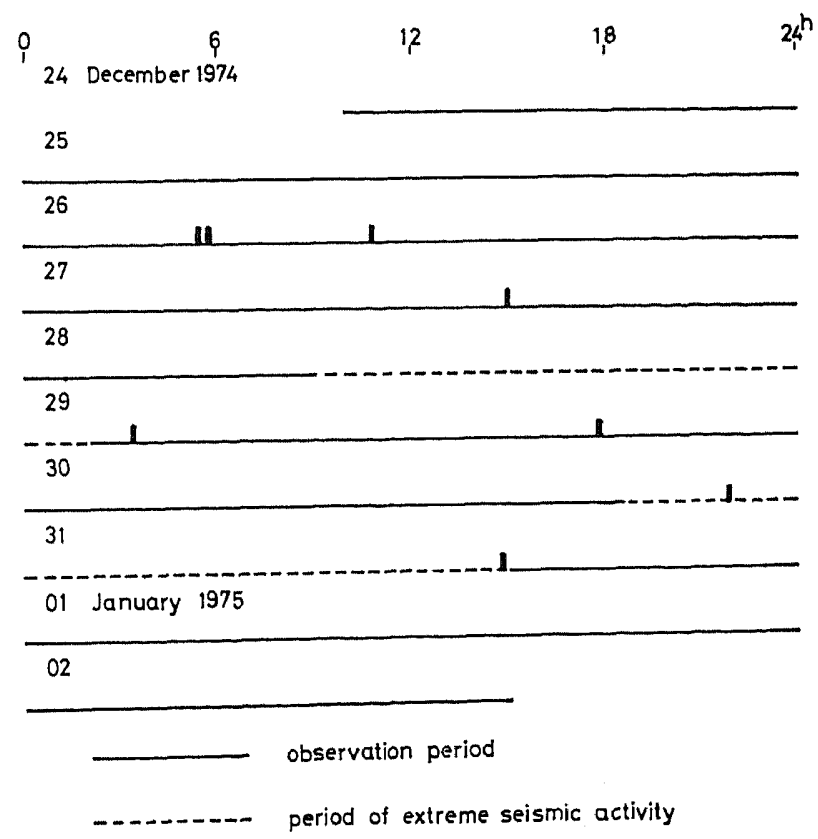

Fig. 9. The time sequence of earthquake occurrence observed at Arrival Heights of McMurdo from December 24, 1974 to January 2, 1975. Solid columns show the periods of extreme seismic activity. 
center determination of earthquakes was not successful because the seismogram at the observation point near First Crater recorded a large seismic tremor through all of the observation period.

The time sequence of earthquake occurrence was shown in Fig. 9. Eight micro-earthquakes with S-P times less than $10 \mathrm{sec}$ were identified during a 9day period. The real observation period was 8 days because the periods of extreme microseismic activity were excluded from the record. The magnitudes of the earthquakes were around 0 . Some ice shocks were also recorded by the observation network, but it is easy, in general, to distinguish between micro-earthquakes and ice shocks from their wave forms.

No small and/or minor earthquakes were recorded. The seismicity around the McMurdo Station area is considered to be about 1.0 micro-earthquake per day.

A seismological observation at Lake Leon, in the Taylor Valley, was carried out from 19 to 28 December, 1974. One vertical seismograph and a cassette data recorder with three different magnifications $(5,000,20,000$ and $50,000)$ used for the recording system. The observation point was near the drill hole of DVDP No. 12. As can be seen from the time sequence of earthquake occurrence shown in Fig. 10, four micro-earthquakes with magnitude between 0 and 1 were recorded during a period of 9.5 days. No minor and/or small earthquakes were recorded.

Time sequence of earthquake occurrence at Lake Leon

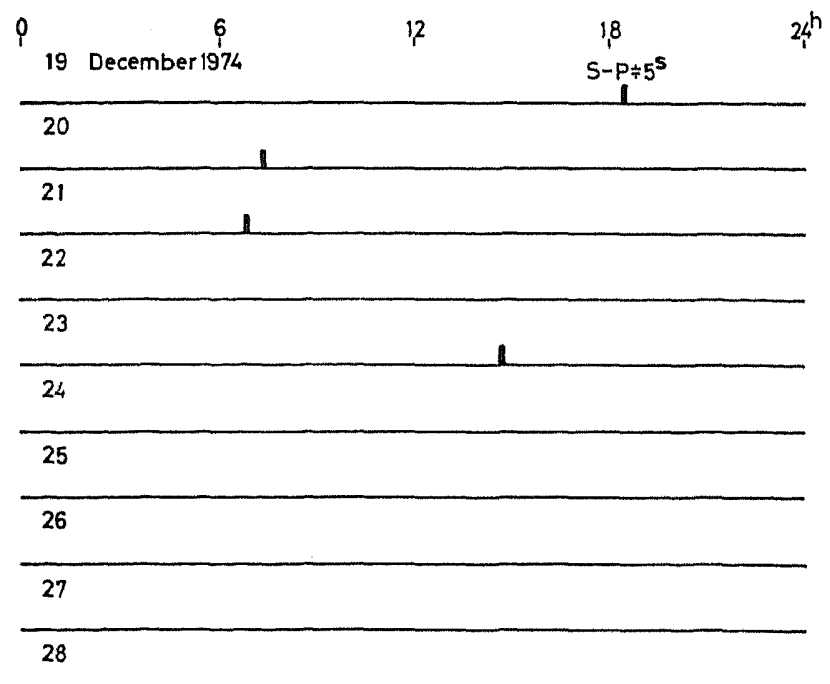

Fig. 10. The time sequence of earthquake occurrence observed at Lake Leon, Taylor Valley from December 19 to 28,1974 . Solid columns show the occurrences of earthquakes. 
The seismicity around the Taylor Valley is approximately one microearthquake every two days.

To confirm the results obtained in the summer season of 1974-75, seismological observations were carried out again at McMurdo Station in 197576. Three seismographs were also installed on the northern foot of Observation Hill.

To avoid artificial noise in daytime, the observations were carried out only at night. A pen recording system with a magnification of 120,000 was used. Thirteen micro-earthquakes with S-P times less than $10 \mathrm{sec}$ were recorded between 15 November and 18 December, 1975. The total time of the observation was $264 \mathrm{hr}, 11$ days. Even though their amplitudes were very small, most of the earthquakes observed at McMurdo were also recognized on a seismogram at Scott Base which is an Antarctic Station of New Zealand and is located about $4 \mathrm{~km}$ east from McMurdo Station (Fig. 8). The seismicity of this observation period was 0.9 micro-earthquake per day. This seismicity is almost the same as that in the previous season. Therefore, we may conclude that the steady state of seismicity around McMurdo Station is about one micro-earthquake per day.

\section{Discussion and Conclusion}

The seismicity around McMurdo Sound is some ten times that around Syowa Station. This fact may indicate that, generally, seismicity in West Antarctica and in the Ross-Weddell Graben is higher than that in East Antarctica.

The seismicity around McMurdo Station is about one micro-earthquake per day and that in the Taylor Valley is 0.5 . The magnification of the instrument used at McMurdo Station is about two times greater than that at Lake Leon. However, considering the higher ground noise around McMurdo Station, the observations at both areas are thought to be detecting earthquakes of the same scale. Micro- and/or ultra micro-earthquake activity around the McMurdo Station area is therefore higher than that around the Dry Valleys. The background seismicity around the McMurdo Sound area is estimated from these observations to be one micro-earthquake every two days. In addition to this background seismicity, one micro-earthquake occurs every two days in the volcanic area around McMurdo Station.

Though small steam eruptions occurred repeatedly at the summit crater of Mt. Erebus through the period of seismological observation, no volcanic earthquakes corresponding to these eruptions were recorded.

There is no close relationship between the high seismicity around McMurdo Station and the volcanic activity of Mt. Erebus, though the seismolog- 
Table 1. Seismicities of volcanic and non-volcanic areas in Antarctica and of volcanic areas in Japan.

\begin{tabular}{lcc}
\hline Station & $\begin{array}{c}\text { Seismicity magnification } \\
\text { of instrument }\end{array}$ & Number of earthquakes \\
\hline McMurdo (74-75) (volcanic) & 100,000 & 1.0 per day \\
(75-76) & 120,000 & 0.9 per day \\
Lake Leon (non-volcanic) & 50,000 & 0.5 per day \\
Syowa (non-volcanic) & 50,000 & 10 per year \\
Japan & & \\
Asama (ERI) & 4,000 & 20 per day \\
Kirisima (ERI) (volcanic) & 10,000 & 0.5 per day \\
\hline
\end{tabular}

ical observation points at McMurdo Station are about $30 \mathrm{~km}$ from the active crater of Mt. Erebus. The higher seismicity in the volcanic area is caused by the structural weakness of the upper crust.

This feature of the seismicity around McMurdo Station located on a volcanic island is very similar to the seismicity around some volcanoes in Japan as given in Table 1. For example about 20 earthquakes which occur in the steady state around the Asama volcano in central Japan are recorded every day at the Asama Volcano Observatory, a branch station of Earthquake Research Institute, the University of Tokyo (private communication). The Asama Volcano Observatory is located $4 \mathrm{~km}$ east of the summit crater of the Asama. Therefore, many earthquakes are recorded. However the seismicity of the area surrounding the Asama is very low.

Records taken by the Kirisima Volcano Observatory, also a branch station of Earthquake Research Institute, show that the seismicity around Kirisima volcanoes, southern Kyushu, Japan, is also 0.5 earthquake in the steady state (KAMINUMA, 1973).

The main results are summarized as follows:

1) Small earthquakes occur at least in West Antarctica and in the RossWeddell Graben, though the activity is very low. But the earthquakes are not generally detectable by the insufficient seismological network in Antarctica.

2) The seismicity around Syowa Station in East Antarctica is less than one micro-earthquake per month. However earthquakes occur in the marginal zone of East Antarctic shield area.

3) The seismicity around the Dry Valleys in Victoria Land is one microor ultra micro-earthquake every two days and that around McMurdo Station on Ross Island is one micro-/ultra micro-earthquake per day.

4) The seismic activity in the volcanic region in Antarctica is relatively higher than that in the surrounding region.

5) The seismicity in West Antarctica and in the Ross-Weddell Graben is some ten times higher than that in East Antarctica. 
Small, micro- and ultra micro-earthquakes were located in the Antarctic Continent. The existence of such seismic activity, however, does not alter the fact that Antarctica is the aseismic continent. Antarctica still has no large earthquakes and a lower seismicity than any other continent. Why no large earthquakes occur in Antarctica is still one of the very important problems of geophysics.

\section{REFERENCES}

Adams, R. D., Small earthquakes in Victoria Land, Antarctica, Nature, 224, 255-256, 1969. Browne-Cooper, P. J., G. R. SMall, and R. Whitworth, Probable local seismicity at Wilks, Antarctica, N.Z.J. Geol. Geophys., 10, 443-445, 1967.

Clarkson, P. D., Geology of the Shackleton Range: A preliminary report, Br. Antarct. Surv. Bull., No. 31, 1-15, 1972.

Evison, F. F., Note on the seismicity of Antarctica, N. Z. J. Geol. Geophys., 10, 479-483, 1967.

Hatherton, T., A note on the seismicity of the Ross Sea region, Geophys. J. R. Astron. Soc., $5,252-253,1961$.

Hatherton, T. and F.F. Evison, A special mechanism for some Antarctic earthquakes, N. Z.J. Geol. Geophys., 5, 864-873, 1962.

Kaminuma, K., The seismological observation and the earthquake detection capability of Syowa Station, Antarctica, Bull. Earthq. Res. Inst., 47, 453-466, 1969.

Kaminuma, K., Syowa-kichi de kansoku shita Bisho-zishin (Micro-earthquakes observed at Syowa Station, Antarctica), Nankyoku Shiryo (Antarct. Rec.), No. 40, 65-73, 1971.

Kaminuma, K., Kakuto karudera no maikuro saisumishitei (The microseismicity in Kakuto Caldera, Kyushu, Japan), Zisin (J. Seismol. Soc. Japan), Ser. 2, 26, 130-141, 1973 (in Japanese).

Kaminuma, K., Seismic activity around McMurdo Sound in Antarctica, Antarct. Rec., No. 56, 22-30, 1976.

KAMINUMA, K. and M. IshidA, Earthquake interpretations at Syowa Station, Antarctica, JARE Data Rep., No. 12, pp. 76, 1971a.

Kaminuma, K. and M. Ishida, Earthquake activity in Antarctica, Antarct. Rec., No. 42, 53$60,1971 b$.

Kogan, S. D., I. P. Pasechik, and D. D. Sultanov, A seismic map of Antarctica, Bull. (Izv.) Acad. Sci. USSR, Geophys. Ser., No. 2, 81-83, 1965 (Engl. transl. by A.G.U.).

Lazareva, A. P. and A. D. Sytinskiy, Seismic observations at Mirny 1961, Inf. Bull. Sov. Antarct. Exp., 5(52), 355-360, 1965.

Takahashi, M., K. Kaminuma, and T. Hirasawa, Nankyoku Syowa Kiti shuhen no shizen zishin (Natural earthquakes around Syowa Station, Antarctica), Abstract of the spring meeting of Seismol. Soc. Japan, No. 1, 61, 1975.

Stephenson, PJ., Geology. 1. Theron mountains, shackleton range and which way nunataks (with a section on palaeomagnetism of the dolerite iutrusions, by D. J. Blundell), Sci. Rep. Transantarct. Exped., No. 88, pp. 79, 1966. 